\title{
PENGEMBANGAN ENERGI TERBARUKAN PADA PULAU-PULAU KECIL
}

\author{
Development Renewable Energi for Small Islands \\ *Mira, Rizki Muhartono dan Siti Hajar Suryawati \\ Pusat Penelitian Sosial Ekonomi Kelautan dan Perikanan \\ Gedung Balitbang KP I Lt. 4 \\ Jalan Pasir Putih Nomor 1 Ancol Timur, Jakarta Utara \\ Telp: (021) 64711583 Fax: 64700924r 2015 \\ *e-mail: miraclenia@yahoo.com
}

Diterima 12 April 2014- Disetujui 25 Mei 2016

\begin{abstract}
ABSTRAK
Penelitian ini bertujuan untuk melihat optimasi potensi pengembangan energi terbarukan dengan melihat aspek dari sisi suplai (potensi energi) dan dari sisi demand (potensi konsumen). Metode analisis data yang digunakan adalah analisis multikriteria dengan membuat prioritasi melalui bobot dan scoring. Hasil analisis skala prioritas wilayah pengembangan energi terbarukan mengindikasikan dari 5 wilayah yang disurvei, wilayah yang menjadi prioritas pengembangan energi gelombang dan arus laut dari prioritas tertinggi sampai terendah dengan skala prioritas masing-masing $(0.76,0.67,0.65$, $0.61,0.51$ ) adalah Raja Ampat, Larantuka, Bawean, Nusa Penida, dan Kabupaten Bangka. Sedangkan wilayah yang menjadi kurang prioritas dalam pengembangan energi terbarukan adalah Kabupaten Bangka, di Kecamatan Belinyu. Hal ini disebabkan dari sisi potensi arus tidak masuk dalam Arus Laut Indonesia (Arlindo) yang berpotensi untuk pengembangan energi arus. Guna mengoptimalkan potensi energi terbarukan seperti gelombang dan arus laut maka pengembangan energi terbarukan (arus dan gelombang laut) diharapkan secara teknis mudah dilaksanakan oleh masyarakat (kalau bisa teknologi yang digunakan harus disederhanakan), hal ini berkaitan dengan perawatan pasca pengembangan energi terbarukan terutama di pulau-pulau kecil.
\end{abstract}

Kata Kunci: konsumen, energi terbarukan, arlindo, arus, gelombang

\section{ABSTRACT}

The purpose of this study is to analyze the optimization potential renewable energi with a view aspects of the supply side (potential energi) and the demand side (potential consumers). Data analysis method used was multi-criteria analysis to make prioritization through weighting and scoring. The results of the analysis of priorities indicated from five regions surveyed, priority areas the development of energi waves and ocean currents from highest priority to lowest priority scale respectively $(0.76,0.67,0.65$, $0.61,0.51)$ is Raja Ampat, Larantuka, Bawean Nusa Penida, and Bangka. Instead region becomes less priority in the development of renewable energi is Bangka, in the District Belinyu, because Bangka not included in the Indonesian Seas Flow (Arlindo). Development of renewable energi is expected to be technically easy to implement by the community (if it can be simplified technology used), it relates to the post-treatment of renewable energi development, especially in small islands.

Keywords: consumer, renewable energy, arlindo, currents, waves 


\section{PENDAHULUAN}

Energi berperan sangat penting dalam mendorong pertumbuhan ekonomi, hal ini tercermin dari hubungan elastisitas energi. Dalam hubungan elastisitas energi (pertumbuhan konsumsi energi sebagai akibat perubahan kegiatan ekonomi, di Indonesia diasumsikan pertumbuhan konsumsi energi akan meningkat $10 \%$ jika pertumbuhan ekonomi meningkat sebesar $7 \%$. Di sektor perikanan misalnya, pentingnya energi bisa dilihat dari kontribusi Kontribusi Bahan Bakar Minyak (Bahan Bakar Minyak) terhadap struktur biaya operasional penangkapan ikan mencapai $40 \%$. Meningkatnya kebutuhan akan energi listrik yang terjadi di Indonesia perlu adanya pasokan sumber pembangkit listrik yang terbarukan dan ramah lingkungan mengingat sumber pembangkitnya semakin menipis (Theoyana, 2015).

Pemakaian bahan bakar fosil ini pun semakin hari semakin meningkat sedangkan cadangan bahan bakar fosil dunia kian menipis. Jika terjadi kelangkaan BBM yang akan menyebabkan kenaikan harga BBM, tentu saja akan mengurangi keuntungan yang diterima nelayan, bahkan akan mengancam usaha perikanan tangkap. Di sisi lain, cadangan sumber energi menimbulkan kekuatiran. Guna mengatasi kelangkaan energi maka banyak yang dilakukan diantaranya adalah mengganti sumber energi fosil dengan energi terbarukan atau melakukan penghematan energi.

Kelangkaan bahan bakar minyak menyebabkan kenaikan harga minyak dunia yang signifikan, telah mendorong pemerintah Indonesia untuk mengajak masyarakatmengatasi masalah energi bersama-sama. Keadaan inilah yang kemudian memaksa masyarakat untuk kembali ke bahan bakar yang berasal dari alam maupun tumbuhan (bahan yang terbarukan). Adapun bahan bakar yang berasal dari alam, terutama yang ada di lingkungan masyarakat pesisir adalah angin laut, gelombang laut dan arus laut. Namun pemanfaatan energi ini belum begitu banyak, salah satunya disebabkan oleh sedikitnya penelitian yang membahas aspek suplai dan konsumen energi terbarukan yang berasal dari angin laut, gelombang, dan arus laut. Namun sebelum dikembangkan, tentu saja teknologi ini harus diperkenalkan ke masyarakat biar tepat guna.
Sumber energi terbarukan banyak ditemukan di Indonesia, diantaranya pohon jarak, rumput laut, angin laut, gelombang laut, dan arus laut. Namun penelitian mengenai energi terbarukan dengan memanfaatkan angin laut, gelombang laut, dan arus laut yang meninjaunya dari aspek suplai dan demand adalah sangat minim. Parameter untuk optimasi pengembangan energi terbarukan yang perlu dilihat adalah suplai (potensi energi gelombang dan arus) dan dari sisi demand (potensi konsumen). Pada awalnya banyak parameter yang dimasukan, tapi ada beberapa parameter yang tidak bisa dijawab oleh responden, sehingga ada beberapa parameter yang tidak dimasukkan dalam model prioritas wilayah pengembangan energi terbarukan. Pada penelitian ini akan dibahas wilayah prioritas pengembangan energi terbarukan dengan melihat aspek secara holistik baik sisi potensi energi dan dari sisi potensi konsumen.

\section{METODOLOGI}

\section{Waktu dan Lokasi Penelitian}

Penelitian dilakukan pada tahun 2014. Lokasi penelitian yang dipilih adalah Pulau Bawean, Kabupaten Gresik (Jawa Timur), Tanjung Menangis, Kabupaten Lombok Timur (Nusa Tenggara Barat), Kabupaten Raja Ampat (Papua Barat), dan Nusa Penida, Kabupaten Klungkung (Bali). Pemilihan lokasi berdasarkan potensi arus dan gelombang yang dimiliki.

\section{Sumber Data dan Cara Pengumpulan Data}

Data yang digunakan berupa data primer dan data sekunder. Ada pun data sekunder diperoleh dari Dinas Pertambangan dan Energi, Bappeda, dan Biro Pusat Statistik. Data primer diperoleh merupakan wawancara dengan masyarakat calon pemanfaat energi terbarukan, tokoh masyarakat, pengurus koperasi, dan pelaku usaha di bidang perikanan dan pariwisata. Responden calon konsumen diambil dari wilayah yang memiliki potensi dan rasio elektrifikasinya yang masih rendah.

\section{Metode Analisis Data}

Parameter untuk pengembangan energi terbarukan dapat dilihat pada dua sisi, yaitu dari potensi dan pihak permintaan dalam hal 
ini adalah calon konsumen dan respon mereka terhadap energi terbarukan baik masyarakat maupun dari pemerintah daerah. Prioritasi wilayah pengembangan energi terbarukan dari arus dan gelombang laut dilakukan dengan kuantitatif deskriptif untuk sejumlah faktor yang merupakan komponen faktor penentu dalam pengembangan energi terbarukan. Adapun komponen faktor penentu tersebut langkahnya bobot dan skoring. Bobot dan skoring dilakukan pada masing-masing parameter dari kuesioner yang diisi oleh responden. Bobot bisa dilakukan karena obyek yang berasal dari derivative (turunan) suatu objek, yang pada kuesioner tertera mengandung kategori untuk pengukuran penilaian. Dimana skala pengukuran untuk bobot dan skoring adalah sebagai berikut:

$$
\begin{aligned}
& 1=\text { Kecil } \\
& 2=\text { Sedang } \\
& 3=\text { Besar }
\end{aligned}
$$

Data tentang aspek konsumen dikelompokkan berdasarkan jawaban yang sama. Responden memberi penilaian terhadap faktor-faktor yang mempengaruhi mereka (Salomon, 1996) memilih energi terbarukan dari angin/ gelombang/ arus laut. Misalnya mereka memilih penggunaan energi terbarukan karena harga, faktor aksesibilitas, atau faktor pertimbangan keamanan (tidak merusak mesin kapal).

\section{HASIL DAN PEMBAHASAN}

\section{Wilayah Prioritas Pengembangan Energi Terbarukan}

Hasil analisis mengindikasikan dari 5 wilayah yang disurvei, wilayah yang menjadi prioritas pengembangan energi gelombang dan arus laut dari prioritas tertinggi sampai terendah adalah Raja Ampat, Larantuka, Bawean, Nusa Penida, dan Kabupaten Bangka. Secara potensi, Larantuka memiliki potensi arus yang cukup besar dimana kecepatan arus mencapai $(4 \mathrm{~m} /$ detik). Tapi Raja Ampat $(0,11 \mathrm{~m} / \mathrm{det})$ menjadi prioritas karena meskipun secara potensi lebih kecil ketimbang Larantuka, dari segi potensi konsumen cukup besar.

Sedangkan wilayah yang menjadi kurang prioritas dalam pengembangan energy terbarukan adalah Kabupaten Bangka, di Kecamatan Belinyu. Hal ini disebabkan dari sisi potensi arus tidak masuk dalam Arus Laut Indonesia (Arlindo) Yang Berpotensi Untuk Pengembangan Energi Arus, dari sisi konsumen juga tidak mendapat respon yang baik. Bawean menjadi pengembangan energi terbarukan, karena memiliki gelombang yang cukup besar, tapi juga didukung oleh faktor aksesibilitas pulau tersebut yang terpencil dibanding wilayah lain. Hal ini menyebabkan keengganan PLN untuk membangun kabel bawah laut. Selama ini PLN mengandalkan sumber energy dari diesel.

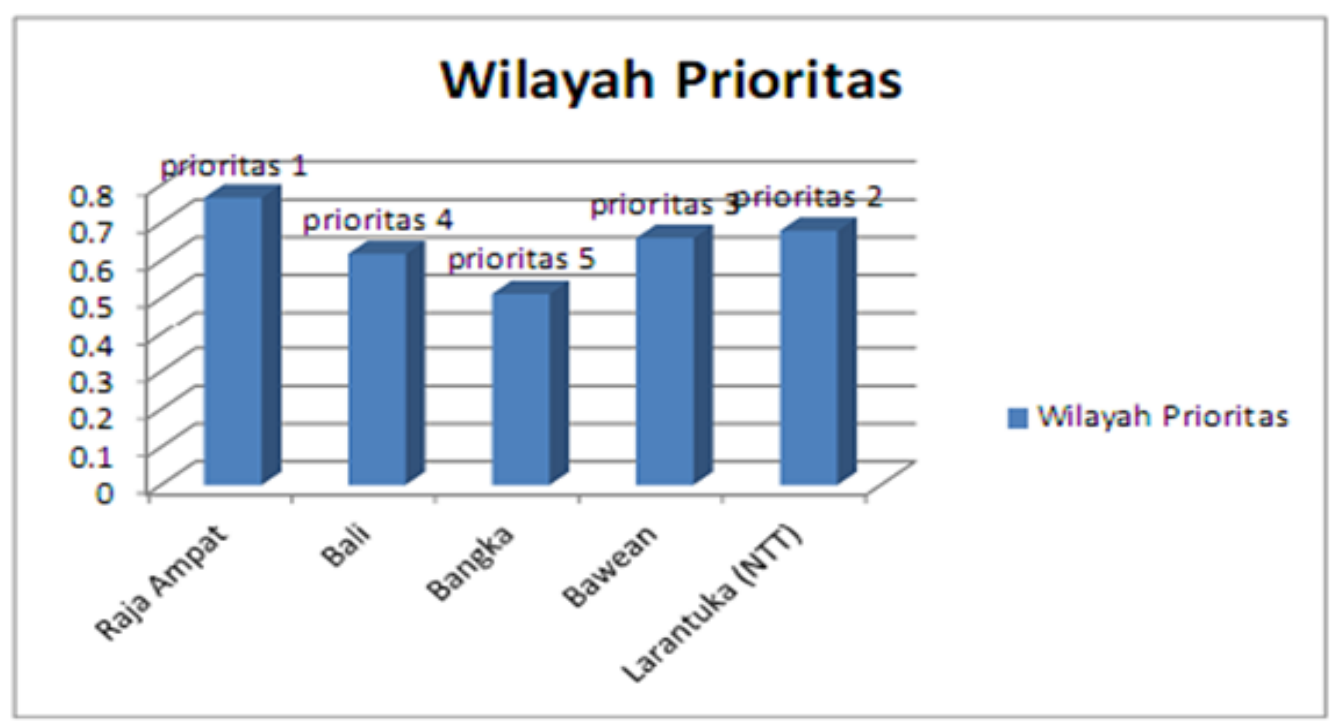

Gambar 1. Wilayah Prioritas Pengembangan Energi Terbarukan di Indonesia Sumber:Data diolah, 2016 


\section{Potensi Arus dan Gelombang Untuk Pengembangan Energi Terbarukan}

Lokasi yang dikunjungi (Raja Ampat) memiliki potensi energi terbarukan yang bersumber dari arus, dimana dua lokasi penelitian memiliki potensi arus. Berdasarkan hasil penelitian dari Badan Pusat Pengembangan Teknologi dan Pusat Penelitian PLN potensi arus antara Nusa Penida dan Lembongan mampu menghasilkan listrik sebesar $20 \mathrm{KW}$ (kilo watt). Potensi arus tersebut jika dibandingkan dengan biaya yang dikeluarkan untuk investasi pengembangan energi terbarukan adalah tidak sebanding. Hal ini dikarenakan daya yang dihasilkan hanya $20 \mathrm{KW}$, dimana menurut wawancara dengan pihak PLN di lokasi penelitian, daya tersebut hanya mampu mengaliri listrik untuk 30 KK (Kepala Keluarga) dengan spesifikasi untuk kategori konsumen R1 (kategori pemakaian daya paling kecil yang masih diberikan subsidi oleh pemerintah). Berdasarkan kesimpulan dari wawancara, pengembangan energi terbarukan dari arus laut di Nusa Penida cukup berat, karena antara kebutuhan investasi dan arus yang dihasilkan tidak sepadan.

Berdasarkan uji lapang yang dilakukan oleh tim PPGL-ESDM dan Institut Teknologi Bandung (ITB) di Nusa Lembongan (Nusa Penida), arus yang dihasilkan dari turbin yang dikembangkan oleh tim tersebut adalah masuk dalam kategori skala kecil karena hanya menghasilkan energi 5.000 watt (KESDM, 2011).
Dengan asumsi efisiensi turbin sebesar 0,593 dan menggunakan kecepatan arus rata-rata selama satu periode pasang surut (residual current) untuk tidal constant M2, potensi daya listrik di beberapa tempat di Selat Bali pada kedalaman 12 meter, kondisi pasang perbani, dapat mencapai $300 \mathrm{KW}$ bila menggunakan daun turbin dengan diameter 10 meter (Setiawan, et al., 2011).

Berdasarkan laporan penelitian tim PPGL-ESDM dan ITB yang diunduh oleh Humas Ristek, maka hasil uji lapangan disampaikan bahwa lokasi penempatan turbin arus pada lokasi perairan sisi timur Nusa Lembongan dengan jarak dari lokasi ke perumahan penduduk tidak terlalu jauh mempunyai morfologi relatif landai dengan kedalaman \pm 20 meter, dan masih dilalui arus cukup kuat (KESDM, 2011). Berdasarkan harga kecepatan arus yang ada, durasi kecepatan arus yang lebih dari $1,5 \mathrm{~m} /$ detik dan distribusi kecepatan arus terhadap kedalaman kolom air, maka lokasi ini cukup representatif untuk rencana pemasangan pembangkit listrik tenaga arus. Namun, secara skala ekonomi, pengembangan energi arus laut ini masih cukup berat. Apalagi untuk bagian tengah Selat Toyapakeh yang kondisi karakteristik pantai dan morfologi dasar lautnya mempunyai kemiringan lereng yang terjal dengan kemiringan hingga 700 dan kedalaman mencapai lebih dari 200 meter, sehingga kurang sesuai untuk pemasangan turbin, meskipun secara distribusi kecepatan arus memenuhi syarat untuk pengembangan energi terbarukan dari arus laut.

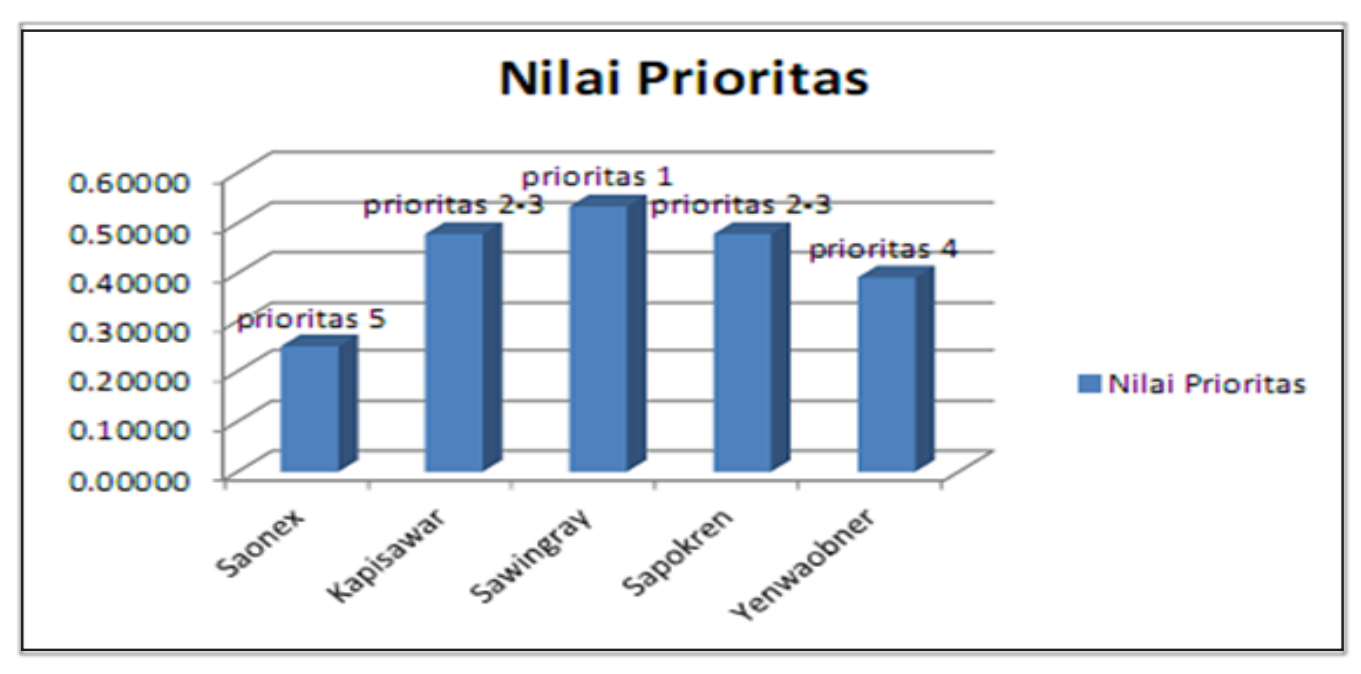

Gambar 2. Wilayah Prioritas Pengembangan Energi Terbarukan di Raja Ampat Sumber:Data diolah, 2016 
Potensi energi arus di Raja Ampat berdasarkan pengamatan yang dilakukan oleh Kajian Litbang ESDM, cukup besar, dimana terpusat di sekitar Pulau Sawiray dan Pulau Kapisawar. Berdasarkan laporan yang dibuat oleh Coremap II (2008), kecepatan rata-rata arus di Perairan Raja Ampat sekitar 0,11 m/ detik. Arus diperkirakan kencang pada saat duduk tengah pasang atau duduk tengah surut (Azis, 2006). Daerah-daerah yang diperkirakan mempunyai arus pasang surut yang deras antara lain Selat Mansuar, Selat Kabui, dan Selat Sagawin.

Rencananya, Puslitbang ESDM akan membangun proyek energi arus di Selat Mansuar yang terletak antara Pulau Sawiray dan Pulau Kapisawar. Artinya, Puslitbang ESDM menggunakan arus laut yang dipengaruhi oleh pasang Surut. Berdasarkan laporan dari Mambrisaw et al. (2006), didapatkan bahwa arus di Perairan Raja Ampat didominasi oleh pengaruh angin, namun untuk wilayah teluk dan pulau-pulau kecil yang berdekatan pola arusnya lebih dipengaruhi oleh pasang surut. Nilai kecepatan arus permukaan lemah pada saat air laut duduk surut atau duduk pasang, sedangkan arus diperkirakan kencang pada saat duduk tengah pasang atau duduk tengah surut (Pranowo, 2006). Berdasarkan laporan Coremap II, kisaran tinggi pasang surut (tidal range) atau perbedaan antara tinggi air pada saat pasang maksimum dan tinggi air pada saat surut minimum berkisar antara 1,15 $-1,80$ meter.
Berdasarkan laporan dari Coremap II, sesuai dengan letaknya, pola arus di perairan Raja Ampat dipengaruhi oleh massa air dari Samudera Pasifik yang bergerak dari arah timur menuju barat laut (North West) dan sejajar dengan daratan Papua bagian utara. Ketika arus tiba di Laut Halmahera atau bagian utara Kepulauan Raja Ampat arus tersebut sebagian bergerak ke selatan dan sebagian berbalik menuju Samudera Pasifik. Arus yang dikenal sebagai Halmahera Eddie ini, kemudian sebagian memasuki perairan Kepulauan Raja Ampat. Hal ini berarti bahwa, arus laut di Raja Ampat termasuk pada Arus Lintas Indonesia (Arlindo) yang diprediksi mampu menghasilkan daya listrik yang cukup kuat.

Menurut (Setiawan et al., 2011) Arlindo adalah suatu sistem di perairan Indonesia di mana terjadi lintasan arus yang membawa massa air dari Lautan Pasifik ke Lautan Hindia. Massa air Pasifik tersebut terdiri atas massa air Pasifik Utara dan Pasifik Selatan. Terjadinya arlindo terutama disebabkan oleh bertiupnya angin pasat tenggara di bagian selatan Pasifik dari wilayah Indonesia. Angin tersebut mengakibatkan permukaan bagian tropik Lautan Pasifik Barat lebih tinggi dari pada Lautan Hindia bagian timur. Hasilnya terjadinya gradien tekanan yang mengakibatkan mengalirnya arus yang kuat dari Lautan Pasifik ke Lautan Hindia. Arus lintas Indonesia selama Muson Tenggara umumnya lebih kuat dari pada di Muson Barat Laut.

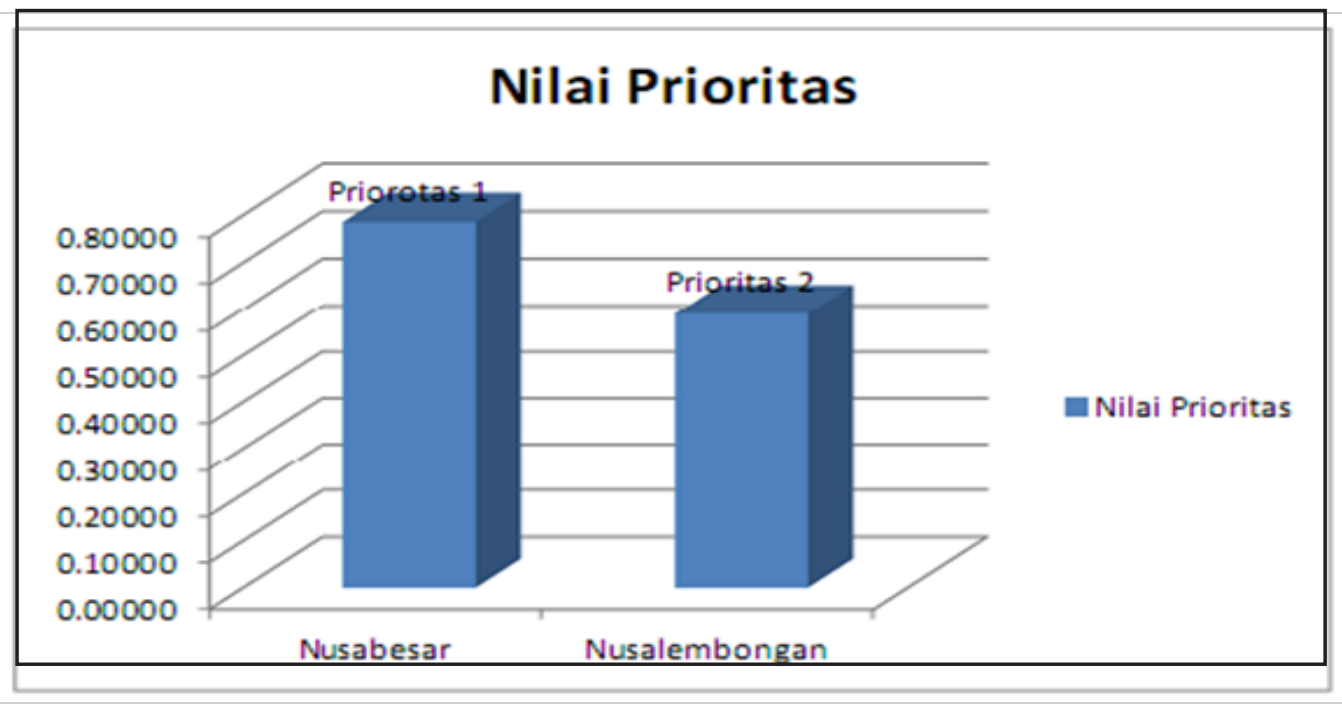

Gambar 3. Wilayah Prioritas Pengembangan Energi Terbarukan di Bali

Sumber:Data diolah, 2016 
Diprediksi nilai-nilai kecepatan arus di Arus Lintas Indonesia (Arlindo) ini adalah mempunyai nilai minimal kecepatan arus $\sim 5$ an maksimal $\sim 24$ dengan rata-rata $\sim 15$. Bahkan di sekitar Laut Seram dan Laut Banda arus Arlindo melimpah dari $1.250 \mathrm{~m}$ (Setiawan et al., 2011). Diperkirakan potensi arus di sepanjang Arlindo adalah 5,6-9 terrawatt berdasarkan hasil proyek Arus Lintas Indonesia (Arlindo). Apabila dikonversikan menjadi listrik, arus laut Indonesia bisa mencapai 30.000 hingga 50.000 kali lipat dari kapasitas PLTA Jatiluhur 187 MW (Anomimous, 2011).

Selain itu pola arus di Perairan Raja Ampat dipengaruhi olehArus Khatulistiwa Utara danArus Khatulistiwa Selatan. Arus Khatulistiwa Utara, merupakan arus panas yang mengalir menuju ke arah barat sejajar dengan garis khatulistiwa dan ditimbulkan serta didorong oleh angin pasat timur laut, sedangkan Arus Khatulistiwa Selatan, merupakan arus panas yang mengalir menuju ke barat sejajar dengan garis khatulistiwa. Arus ini ditimbulkan atau didorong oleh angin pasat tenggara. Artinya, energi arus di Raja Ampat selain didukung dari arus Fasifik juga didukung oleh arus Katulistiwa Utara dan Selatan.

\section{Potensi Konsumen Pengembangan Energi Terbarukan (Gelombang dan Arus)}

Salah satu hal yang menjadi kendala dalam pengembangan energi arus ini, adalah masih adanya subsidi listrik dari pemerintah, sehingga pengembangan energi arus dalam hal ini energi terbarukan tidak layak secara ekonomis, selama energi listrik masih disubsidi pemerintah. Hal ini dikarenakan untuk pengembangan energi dari arus laut membutuhkan investasi yang cukup besar. Padahal jika dilihat dari potensi konsumen baik dari RTP dan maupun konsumen untuk usaha skala kecil (homestay) maka pengembangan energi terbarukan layak dilakukan, misalnya didua lokasi Penelitian, terutama untuk Raja Ampat sangat memiliki potensi yang cukup besar. Karena rasio elektrifikasi di Raja Ampat masih rendah yaitu baru 70\% (Gambar 5).

Potensi konsumen baik dari RTP dan maupun konsumen untuk usaha skala kecil (homestay) maka pengembangan energi terbarukan layak dilakukan didua lokasi Penelitian, terutama untuk Raja Ampat sangat memiliki potensi yang cukup besar. Karena rasio elektrifikasi di Raja Ampat masih rendah yaitu baru $70 \%$. Sedangkan rasio elektrifikasi di Nusa Penida sudah $90 \%$, apalagi tahun ini di Nusa Penida sudah dibangun kabel bawah laut. Potensi konsumen dari skala UKM hanya terbatas pada kebutuhan Homestay, karena usaha yang berkembang adalah usaha wisata.

Di Raja Ampat pemenuhan kebutuhan listrik homestay diperoleh dengan menggunakan Diesel terutama pulau-pulau kecil, energi terbarukan seperti energi surya hanya mampu mengaliri listrik untuk lampu kamar. Tapi ada juga homestay yang menggunakan energi

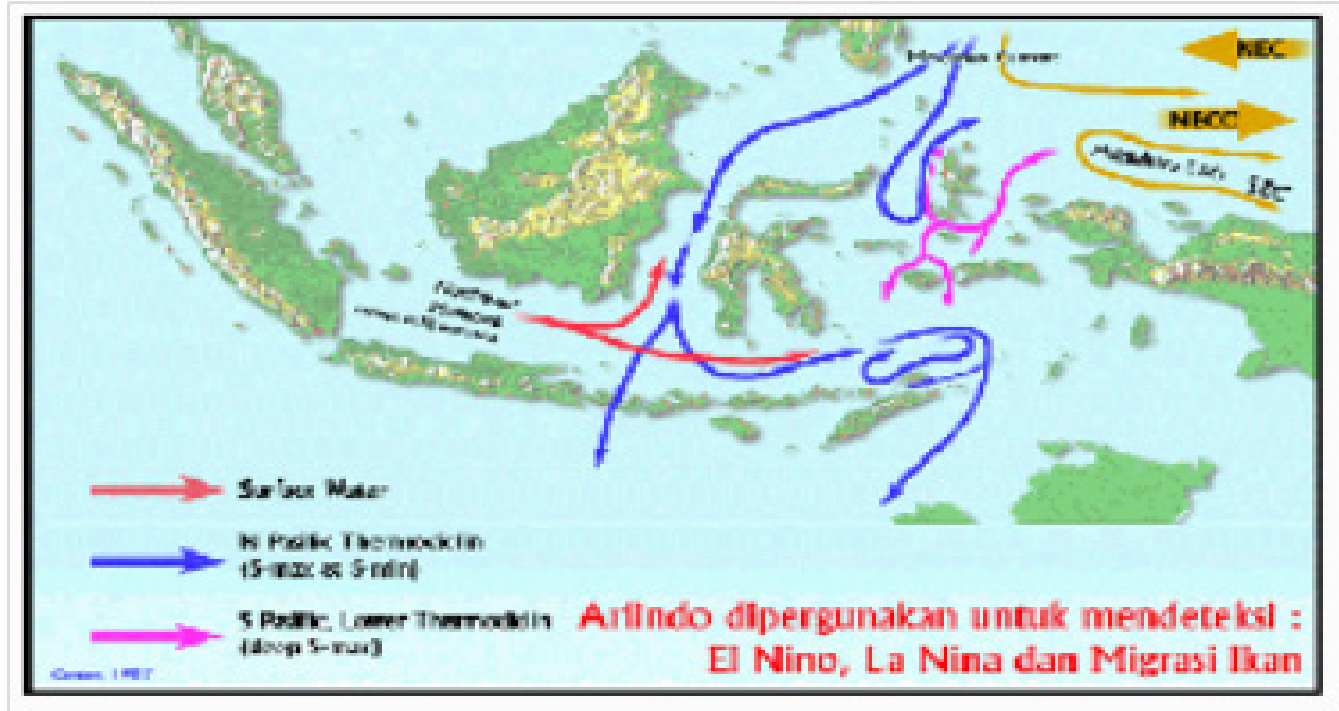

Gambar 4. Arus Laut Indonesia (Arlindo) Yang Berpotensi Untuk Pengembangan Energi Arus Sumber: Setiawan, F, et al, 2011 
surya. Namun sesuai dengan potensi yang dimiliki, maka pulau wisata yang mampu memiliki potensi arus hanya di Pulau Kapisawar dan Pulau Sawiray. Salah satu yang menjadi kendala dalam hal potensi konsumen adalah masalah keberlanjutan pemeliharaan hasil bantuan alat dari energi terbarukan. Meski, secara konsumen ada potensinya, namun jika masyarakat tidak merawat alat tersebut, karena menganggap program tersebut hanya hibah, maka pengembanganj energi terbarukan tidak optimal, artinya sangat diperlukan partisipasi masyarakat dari sejak awal proyek ini diberikan.

Pemerintah harus mengurangi subsidi terhadap bahan bakar minyak dan memperbesar subsidi untuk energi terbarukan seperti energi arus dan gelombang laut, karena selama harga BBM lebih rendah dari harga energi terbarukan maka pengembangan energi terbarukan tidak kompetitif. Kelebihan dari masing-masing wilayah adalah dari segi potensi, misalnya di Raja Ampat dan Nusa Lembongan. Namun jika potensi tersebut dibandingkan biaya investasi dan biaya perawatan tidak sebanding, apalagi mengingat kebijakan pemerintah yang masih memberikan subsidi terhadap BBM. Selama kebijakan subsidi terhadap BBM masih ada pengembangan energi terbarukan tidak kompetitif. Berdasarkan hasil penelitian dari Badan Pusat Pengembangan Teknologi dan Pusat Penelitian PLN potensi arus antara Nusa Penida dan Lembongan mampu menghasilkan listrik sebesar $20 \mathrm{KW}$ (kilo watt).

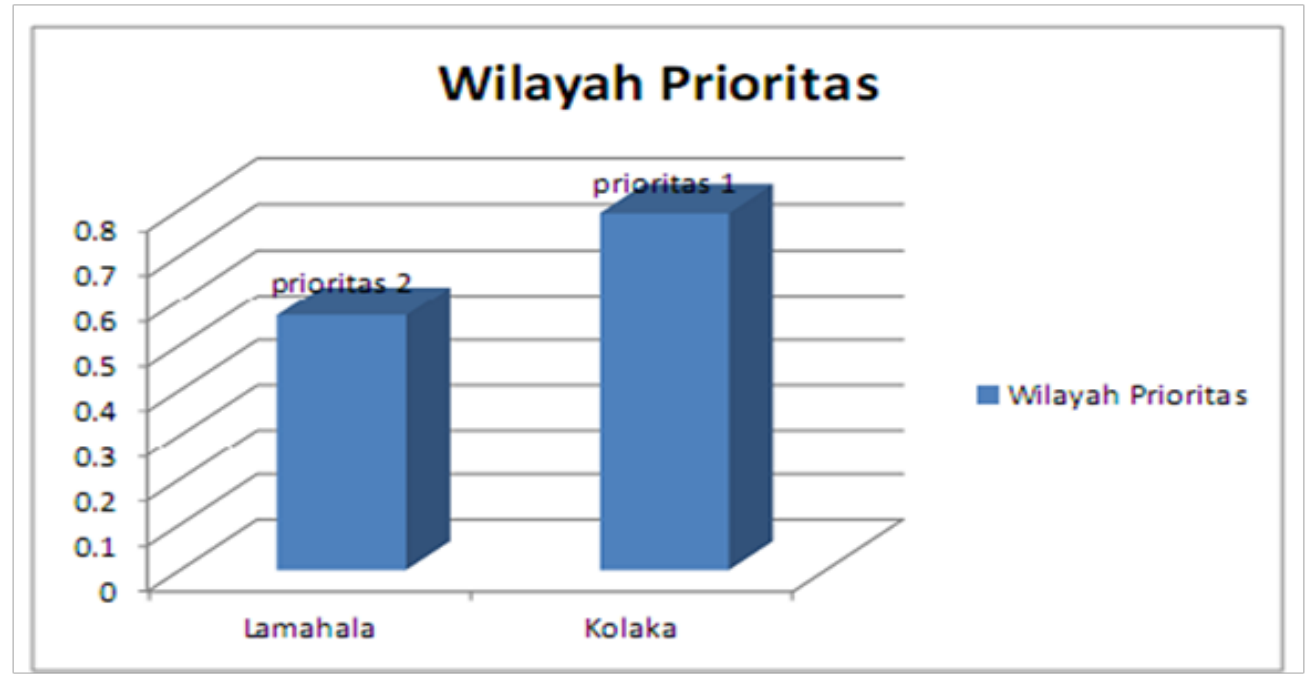

Gambar 5. Wilayah Prioritas Pengembangan Energi Terbarukan di Lombok Timur Sumber:Data diolah, 2016

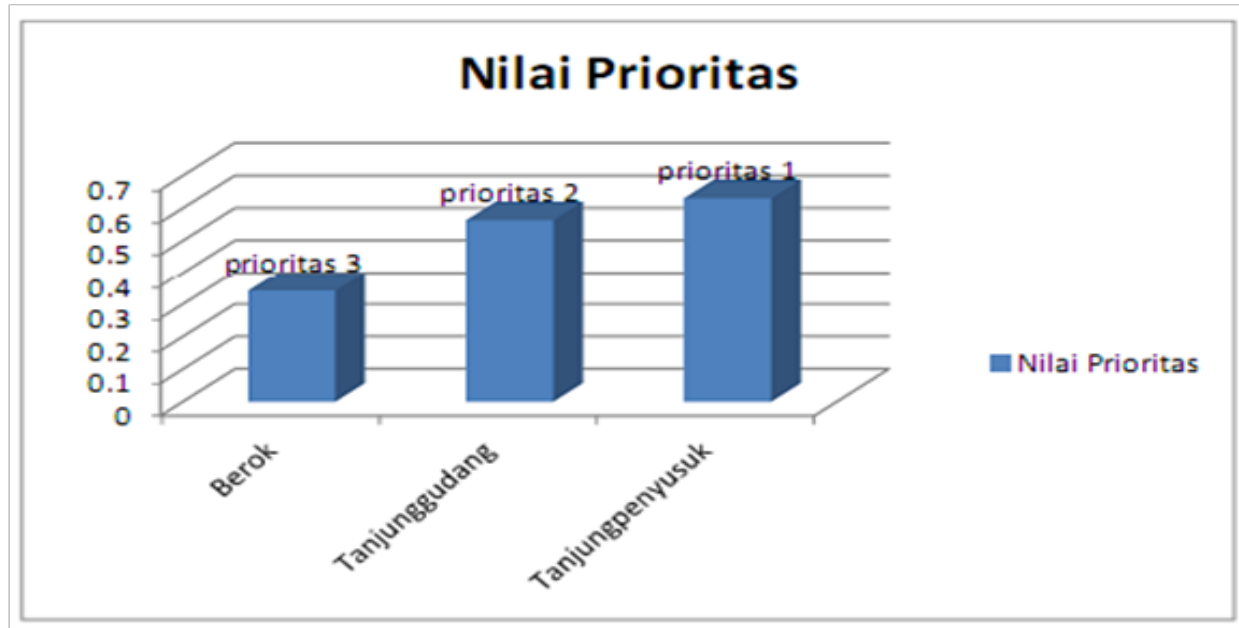

Gambar 6. Wilayah Prioritas Pengembangan Energi Terbarukan di Bangka Belitung Sumber:Data diolah, 2016 


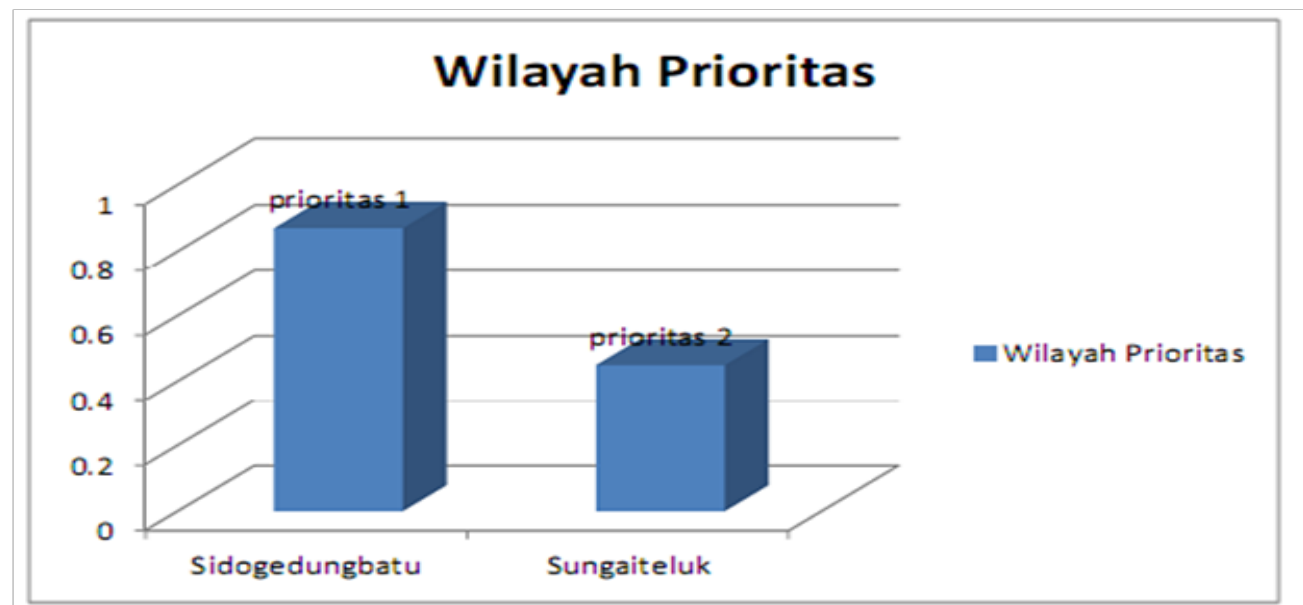

Gambar 7. Wilayah Prioritas Pengembangan Energi Terbarukan di Bawean Sumber:Data diolah, 2016

Potensi arus tersebut jika dibandingkan dengan biaya yang dikeluarkan untuk investasi pengembangan energi terbarukan adalah tidak sebanding. Hal ini dikarenakan daya yang dihasilkan hanya $20 \mathrm{KW}$, dimana menurut wawancara dengan pihak PLN di lokasi penelitian, daya tersebut hanya mampu mengaliri listrik untuk 30 KK (Kepala Keluarga) dengan spesifikasi untuk kategori konsumen R1 (kategori pemakaian daya paling kecil yang masih diberikan subsidi oleh pemerintah). Berdasarkan kesimpulan dari wawancara, pengembangan energi terbarukan dari arus laut di Nusa Penida cukup berat, karena antara kebutuhan investasi dan arus yang dihasilkan tidak sepadan.

\section{KESIMPULAN DAN IMPLIKASI KEBIJAKAN}

Dari hasil analisis skala prioritas dari sisi konsumen (demand), dan dari sisi Suplai (Potensi) maka priortas pengembangan energi terbarukan dari lima lokasi yang disurvei adalah Raja Ampat, Larantuka, Bawean, Nusa Penida, dan Kabupaten Bangka, dengan skala prioritas masing-masing $(0,76 ; 0,67 ; 0,65 ; 0,61 ; 0,51)$. Secara potensi, Larantuka memiliki potensi arus yang cukup besar dimana kecepatan arus mencapai (4 m/detik) menurut Irwandi (2010). Tapi Raja Ampat $(0,11 \mathrm{~m} / \mathrm{det})$ menjadi prioritas karena meskipun secara potensi lebih kecil ketimbang Larantuka, potensi konsumen pengembangan energi terbarukan cukup besar. Sedangkan wilayah yang menjadi kurang prioritas dalam pengembangan energi terbarukan adalah Kabupaten Bangka, di Kecamatan Belinyu.
Hal ini disebabkan dari sisi potensi arus tidak masuk dalam Arus Laut Indonesia (Arlindo) yang berpotensi untuk pengembangan energi arus. Sebelum membangun proyek pengembangan energi terbarukan, sebaiknya melihat tidak hanya dari sisi suplai (potensi) juga dari sisi demand (konsumen), dimana semakin rendah akses masyarakat terhadap PLN seperti pulau-pulau kecil maka semakin besar potensi konsumennya. Hal ini menyebabkan keengganan PLN untuk membangun kabel bawah laut. Selama ini PLN mengandalkan sumber energi dari diesel.

\section{UCAPAN TERIMA KASIH}

Terima kasih kepada perwakilan dari Kepala Dinas Pertambangan dan Energi, Bappeda, dan Biro Pusat Statistik, dan responden yang telah bersedia menyisinkan waktunya untuk menjawab kuesioner dari kami

\section{DAFTAR PUSTAKA}

Azis, M. F. 2006. Gerak Air di Laut. Oseanografi, Institut Teknologi Bandung: Bandung.

Kementerian Energi dan Sumber Daya Mineral (KESDM).2011. Pengembangan Energi Arus Laut. Diunduh 15 agustus 2014. Tersedia pada: http://ebtke.esdm.go.id/ post/2011/04/25/138/pengembangan.energi. arus.laut.

Mambrisaw, A., B. Wurkianty, F. Liuw, S. Hamel, A. A. Mulyadi, A. Sukmara, H. Sumantri dan Y. Omkarsba. 2006. Atlas sumber daya pesisir Raja Ampat. Conservation International (CI) Indonesia. 
Pranowo, W. S., A. R. T. D. Kuswardhani, T. L. Kepel, U. R. Kadarwati, S. Makarim dan S. Husrin. 2005. Menguak Arus Lintas Indonesia. Departemen Kelautan dan Perikanan: Jakarta.

Salomon, M. R. 1996. Consumer Behaviour. Pretince Hall International.

Setiawan, F. dan A. Qisthy. 2011. Pengembangan Energi Terbarukan dengan Identifikasi Kecepatan Arus Lintas Indonesia di Wilayah Timur Indonesia. diunduh 26 November 2015.
Theoyana, T. A., W. S. Purwanto dan Pranowo. 2015. Potensi Energi Arus Laut Pada Berbagai Kedalaman Untuk Pembangkit Listrik Di Selat Badung, Bali . Jurnal Oseanografi. Volume 4, Nomor 1, Tahun 2015, Halaman 262 - 269 Online di : http://ejournal-s1.undip.ac.id/index. php/jose.

Tresnadi, H. 1998. Pengelolaan Air Tanah Berwawasan Lingkungan di Pulau-Pulau Kecil. Prosiding Seminar Lokakarya Pengelolaan Pulau-Pulau Kecil Indonesia. Jakarta. 7 - 10 Desember 1998. Kerjasama Depdagri, TPSA, BPPT, CRMP, PKSPL-IPB. Jakarta 